\title{
AUTOMATION BENEFITS IN THE FORMATION PROCESS OF LEAD-ACID BATTERIES
}

Márcio Duarte Zanconato

Enerbrax Industry, Brazil

E-mail: zanconato.marcio@gmail.com

Beatriz Braido de Rossi University of Sagrado Coração, Brazil E-mail: beatriz.rossi@hotmail.com

Herbert Duchatsch Johansen University of Sagrado Coração, Brazil

E-mail: hdjohansen@gmail.com

Márcia Rodrigues de Morais Chaves University of Sagrado Coração, Brazil

E-mail: marcia.chaves@usc.br

Beatriz Antoniassi University of Sagrado Coração, Brazil E-mail: beatriz.tavares@usc.br

Submission: 17/06/2016

Revision: 03/07/2016

Accept: 04/08/2016

\section{ABSTRACT}

In this work, the automated formation process of lead-acid battery and its industrial positive impact on the battery efficiency are evaluated toward the manual process. The problems in the lead-acid batteries formation are related to the $\alpha-\mathrm{PbO}_{2}$ and $\beta-\mathrm{PbO}_{2}$ production during the first electric charge. The lead-acid battery formation problems frequently occur when electrical current sources with manual control are used. The main drawback of the manual method is addressed to the electric current interruptions between the plates during the battery charging. Thus, the lead oxides phases in the plates were used as parameter to correlate the chemical composition to the failure on the batteries formation process. X-ray powder diffraction technique was used to identify the lead phases. 
INDEPENDENT JOURNAL OF MANAGEMENT \& PRODUCTION (IJM\&P)

http://www.ijmp.jor.br

v. 8, n. 1, January - March 2017

ISSN: 2236-269X

DOI: $10.14807 /$ ijmp.v8i1.498

The results showed that the use of automated electric power supply has higher efficiency than the manual one. The benefits of automation include the increased productivity, reduction on the production costs, and lower consumption of natural resources.

Keywords: lead-acid battery; automated formation; XRPD, $\mathrm{PbO}_{2}$.

\section{INTRODUCTION}

The electricity discovery has prompted the technological development in various sectors of society, such as lighting, telecommunication system, the ignition for the transport vehicles, among others. Since then, the human being has become dependent on electricity to meet their consumption needs. However, current environmental concerns demand for using alternative energy sources, cleaner and more efficient. It is especially considered when remote areas suffer from a lack of power supply (GUERRA et al. 2015; UGURLU; OZTUNA, 2015; KONOVALOV et al. 2015; SOLOVEICHIK, 2014; GROOS, 2012). Thus, the development of energy storage systems is a key part for this breakthrough to become efficient and feasible (SUBERO et al. 2014; RADUCAN; MORARU, 2011). Among the different types of energy storage systems available, the battery is the most used (JANNATI et al. 2016; TAN et al. 2016; CHO et al. 2015; ZHOU et al. 2013; KEAR et al. 2012).

Lead-acid batteries are the preferred consumed battery systems, by being able to supply power stably and continuously controlled quality when subjected to good maintenance procedures (HIREMATH et al. 2015; MCKENNA et al. 2013). In addition, these types of batteries are manufactured at low cost, with robust recycling production system, and have easy maintenance when compared with other power storage systems (MATTESON; WILLIAMS, 2015; GONZÁLEZ et al. 2012). Its main applications are as a power source for starting, ignition and lighting vehicles, the traction electric vehicles, no-break systems, in alarm systems and emergency lighting, telephone exchanges and electrical substations, featuring applications known as start-up, tractionary and stationary, respectively (MCKEON, 2014; MACLEAN; LAVE, 2003).

Due to their economic and technological importance, the electrochemical system of lead-acid batteries has been the subject of several researches, scientific studies and technical assessments (PITATOWICZ et al. 2015; FERG et al. 2013; 
SAUER; WENZ, 2008). In Brazil, the product quality control occurs through the certification by the National Institute of Metrology, Quality and Technology (INMETRO). This product requires reliability; therefore, is essential the control and track of the entire production process of lead-acid battery (BRAZIL, 2015, 2012, 2011).

The battery formation is one of the most important phases in the production processes of lead-acid batteries. During this process, the precursor material of battery (formed mainly by basic lead oxide and sulfate paste, which is adhered to the grid) is transformed into active material by the passage of electric current. The battery formation step is critical for it works in accordance with what has been dimensioned in its production process (ZENG et al. 2015; GOU et al. 2014; GRUGEON-DEWAELE et al. 1997; CHEN et al. 1996; PROUT, 1993).

The manual process is the main procedure used for the lead-acid battery formation in the most industries in Brazil. Despite of this, some industries are starting the use of the automated process to form lead-acid batteries. To contribute to this field, this work evaluated the automated process of lead-acid battery formation, in attempt to elucidate the effect of electric source control on the battery efficiency.

\section{RESEARCH METHODOLOGY}

The industrial process of the lead-acid battery formation using manual or automated power source is described as following, as well as all the other methodology used in this study.

\subsection{Formation process}

This study was performed in a production of lead-acid VRLA industry (Valve Regulated Lead-Acid) for motorcycles and jet skis, located in the city of Bauru, SP, Brazil (RAND et al. 2004). The company has quality integrated management system and environmental certificates based on standards of the International Organization for Standardization (ISO) and National Standards (NBR) under responsibility of the Brazilian Association of Technical Standards (ABNT) (ABNT, 2008, 2004).

The battery formation starts with the introduction of a sulfuric acid solution, density $1.25 \mathrm{~g} / \mathrm{cm}^{3}$, in the boxes of the batteries containing the positive and negative plates. This step is performed with a filling device aid (Figure 1), and stops when the 
electrolyte transshipment occur (CHEN et al. 1996; PROUT, 1993; KIESSLING, 1992).

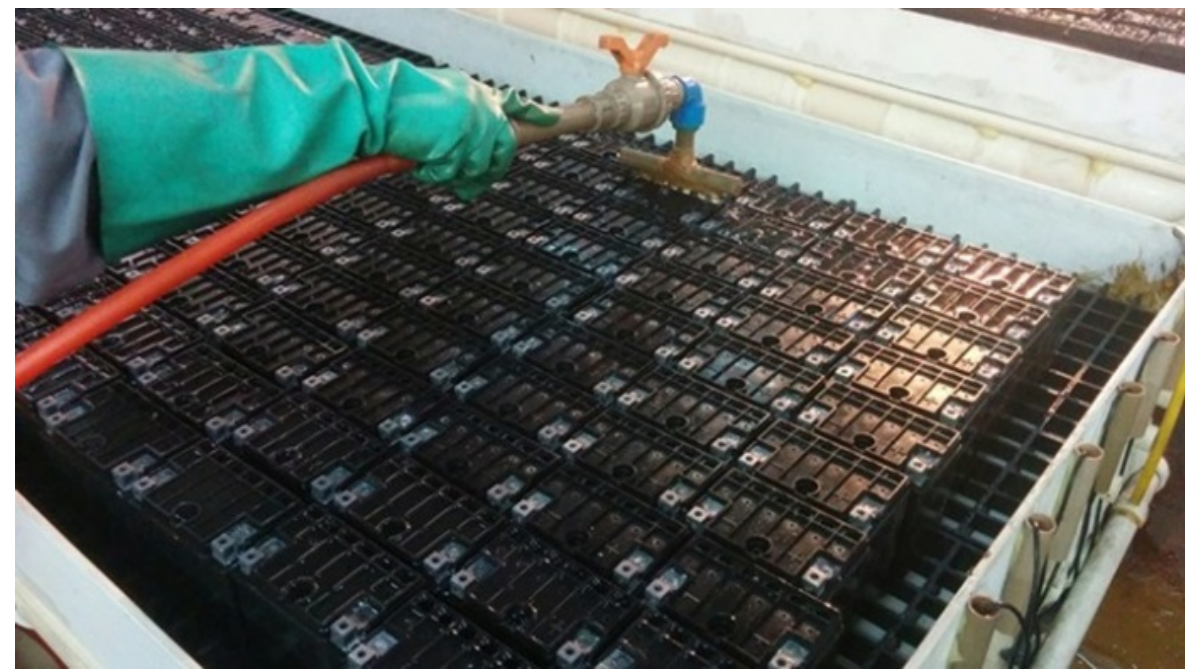

Figure 1: Initial step of the formation process: filling.

After filling, the batteries are allowed to stand in the electrolyte for a period of 2 hours. This resting step is called soaking which corresponds to the chemical reaction between sulfuric acid solution with the oxide and basic lead sulfates resulting in the formation of surface layers of lead sulfate $\left(\mathrm{PbSO}_{4}\right)$ in the plate surfaces and the inner surfaces of their macropores. These layers $\mathrm{PbSO}_{4}$ contribute to electrochemical and thermal balances involved in this stage, increasing the process efficiency (LAWRENCE et al. 2002; LAM et al. 1994). For the production of VRLA batteries, the soaking step coincides with the suitable time for the electrolyte absorption by the tabs (ZENG et al. 2015). After the soaking process, the electrical connections are made in series, every 15 batteries, to be connected to sources of electrical current required to the forming step.

It was conducted a comparative study of the battery formation quality using manual source of electric current (conventional) and an automated source of electric current. In the manual source, the operator controls the time and adjusts the desirable electrical current values; it tends to vary during the charging process. The variation on the electric current is a result of chemical transformations of the precursor materials (of low electric conductivity), to chemical compounds, known as active materials, which are good electrical conductors. When the contact between the electrical conductors is poor, due to oxidation of the terminals and electrical ligaments present between the batteries, it is possible to achieve zero electric 
current. Figure 2 shows the image of a manual power supply control devices. It can be observed that this type of controller is very old, and the high precision in the battery formation process control is not possible to be achieved.

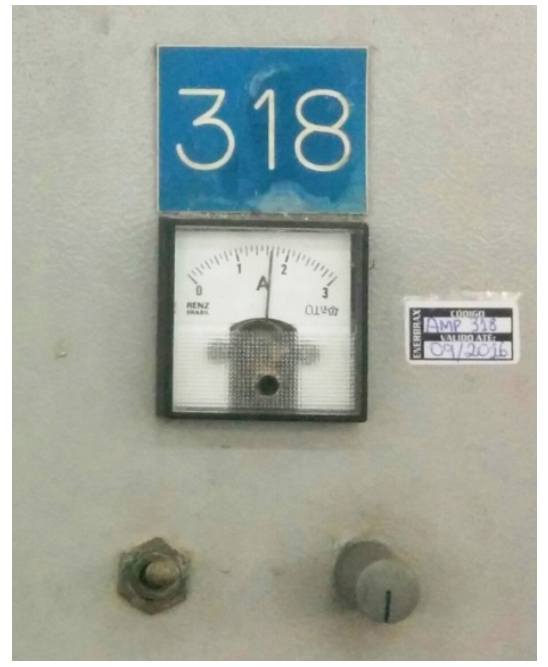

Figure 2: Manual power supply control devices.

The automated equipment incorporates a controller of internal circuit switches, in which the current turns on and off in order to maintain the constant output voltage, that is, one obtains a source of steady electric current. These devices are controlled by software that allows choosing electric current values and application times more accurately than when used analog equipment. Table 1 shows the programming interface of the formation plan of a lead-acid battery.

Table 1: Plan for lead-acid battery formation process. Time is related to the battery permanency under electric charge, break, discharge or recharge.

\begin{tabular}{ccc}
\hline & $\begin{array}{c}\text { Current } \\
(\mathbf{A})\end{array}$ & $\begin{array}{c}\text { Time } \\
\text { (Hour) }\end{array}$ \\
\hline $\mathbf{1}^{\text {st }}$ Charge & 0.6 & 1 \\
$\mathbf{2}^{\text {nd }}$ Charge & 0.6 & 2 \\
$\mathbf{3}^{\text {rd }}$ Charge & 1.5 & 23 \\
$\mathbf{1}^{\text {st }}$ break & 0.0 & 0.25 \\
$\mathbf{4}^{\text {th }}$ Charge & 3.0 & 2 \\
$\mathbf{2}^{\text {nd }}$ break & 0.0 & 0.25 \\
Discharge & 2.0 & 2 \\
Recharge & 1.5 & 8 \\
\hline
\end{tabular}

The battery forming process uses a water cooling system placed beneath the stand, as shown in Figure 3. This process is necessary due to dissipate large quantities of heat, and the temperature increases dramatically. High temperature can 
negatively affect the electrochemical conversion of the active materials precursors (RAND et al., 2004). Figure 3 shows the structure of the stands where the batteries are formed using either manual or automatic current source.

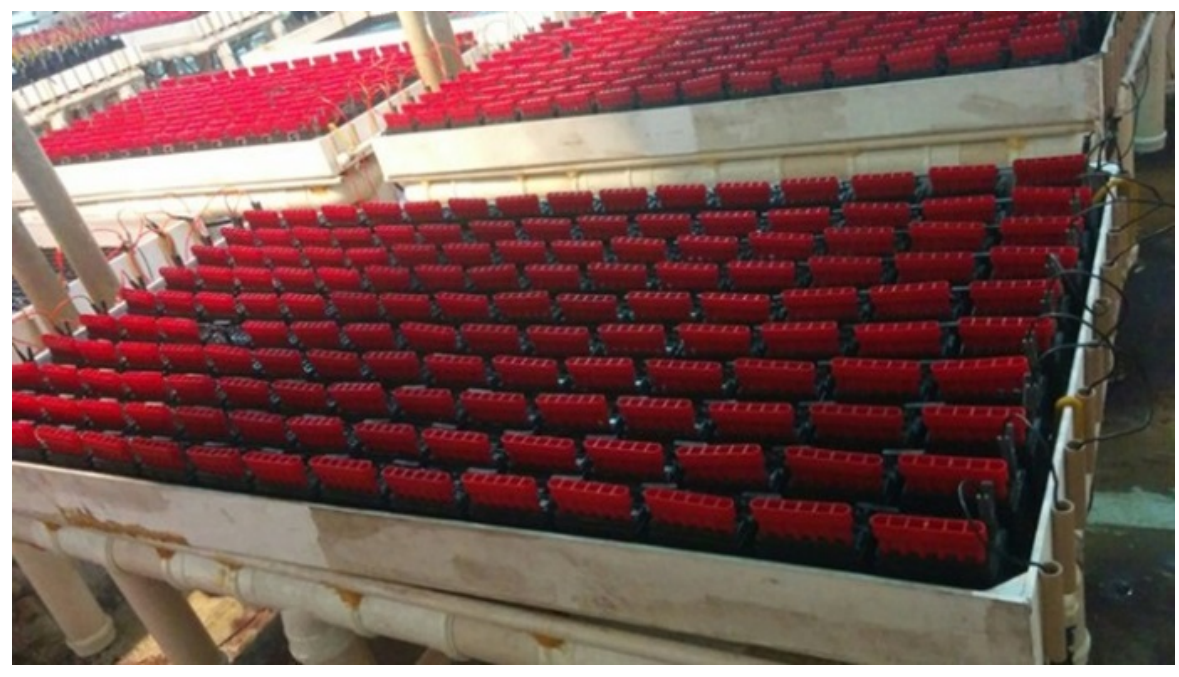

Figure 3: Batteries positioned and ready to connect the source of electric current.

When using the automated source, throughout the process, the software monitors and controls the electrical current and the time for each step of the forming cycle. The high control of formation parameters during the second charge of 10 batteries can be seen in the Table 2 . The average voltage is $178.1 \pm 0.24 \mathrm{~V}$, and the current average is $1.60 \pm 0.02 \mathrm{~A}$. This fine control is considered impossible to be obtained by manual power source. The temperature is controlled independently of the software, the entire process is kept between $35^{\circ} \mathrm{C}<\mathrm{T}<55^{\circ} \mathrm{C}$.

Table 2: Software screen controller entire forming system using the automated source of electric current.

\begin{tabular}{cccccccc}
\hline Stand & Charger & Step & $\begin{array}{c}\text { Voltage } \\
\text { (V) }\end{array}$ & $\begin{array}{c}\text { Current } \\
\text { (A) }\end{array}$ & $\begin{array}{c}\text { Total Time } \\
\text { (hour) }\end{array}$ & $\begin{array}{c}\text { Ampere Hour } \\
\text { (AH) }\end{array}$ & Status \\
\hline $\mathbf{0 0 1}$ & 1 & $2^{\text {nd }}$ Charge & 178.3 & 1.58 & $03: 23: 09$ & 3.65 & Running \\
$\mathbf{0 0 1}$ & 2 & $2^{\text {nd }}$ Charge & 179.0 & 1.59 & $03: 22: 51$ & 2.58 & Running \\
$\mathbf{0 0 1}$ & 3 & $2^{\text {nd }}$ Charge & 179.3 & 1.64 & $03: 22: 37$ & 2.57 & Running \\
$\mathbf{0 0 1}$ & 4 & $2^{\text {nd }}$ Charge & 179.5 & 1.64 & $03: 22: 33$ & 2.57 & Running \\
$\mathbf{0 0 1}$ & 5 & $2^{\text {nd }}$ Charge & 175.3 & 1.61 & $03: 21: 38$ & 2.55 & Running \\
$\mathbf{0 0 1}$ & 6 & $2^{\text {nd }}$ Charge & 176.9 & 1.58 & $03: 21: 17$ & 2.52 & Running \\
$\mathbf{0 0 1}$ & 7 & $2^{\text {nd }}$ Charge & 176.4 & 1.61 & $03: 20: 57$ & 2.53 & Running \\
$\mathbf{0 0 1}$ & 8 & $2^{\text {nd }}$ Charge & 175.5 & 1.60 & $03: 20: 35$ & 2.53 & Running \\
$\mathbf{0 0 1}$ & 9 & $2^{\text {nd }}$ Charge & 177.8 & 1.58 & $03: 20: 12$ & 2.51 & Running \\
$\mathbf{0 0 1}$ & 10 & $2^{\text {nd }}$ Charge & 183.4 & 1.61 & $03: 19: 57$ & 2.50 & Running \\
\hline
\end{tabular}


The parameters of battery formation are easy to be monitored by the industry operators, once all of them are displayed in the power source control screen (Figure 4). This kind of control is important because during the formation process it is possible, for example, reset electrolyte in the batteries in the case of excessive losses due to parallel reactions of water decomposition.

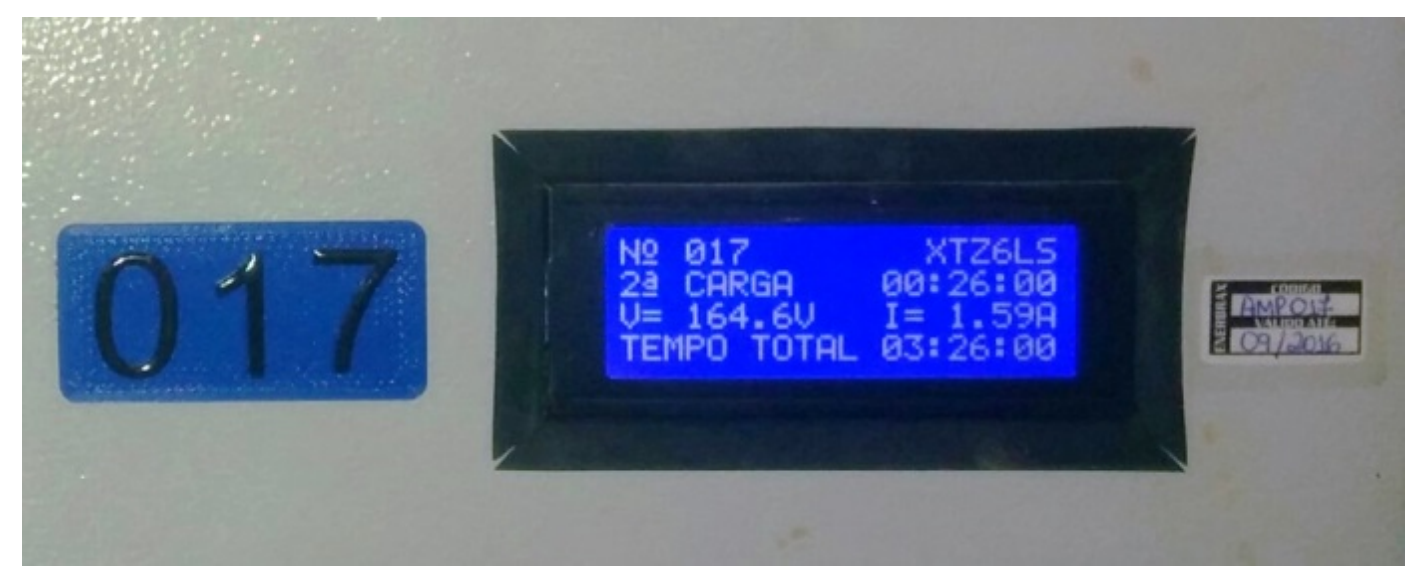

Figure 4: Display indicator of process variables (written in Portuguese).

At the end of this process, in open circuit, the batteries are allowed to cool to $30^{\circ} \mathrm{C}$, so the electrolyte excess is drained, and the forming process is finished.

\subsection{Visual analysis of the lead-acid batteries plates}

In an attempt to obtain an indicative about the efficiency of the formation process, the visual analysis was performed in the positive plate of the battery samples. Samples of new batteries, obtained by automated formation process, as well as samples of returned batteries, obtained by manual formation process, were analyzed. This kind of test is destructive and requires opening the battery to positive plate removal.

The method consisted in visually observing the color throughout the positive plates, as the precursor material initially, basic lead sulfate and lead oxide, have a white or yellow color. The final active material $\left(\mathrm{PbO}_{2}\right)$ is dark brown or black when in the presence of water. The heterogeneous distribution of these colors indicates a low efficiency of the electrochemical formation process, while the uniform distribution of black color indicates a high possibility of a complete formation (PAVLOV, 1984; PAVLOV et al.1972). 


\subsection{X-ray diffraction}

X-ray powder diffraction technique (XRPD) was used to find the predominant chemical composition of the precursor material formed in the positive plate (Watson 1945). The samples obtained to the visual inspection were used to the XRPD analysis (manual and automated formation process), as well as the material of the positive plate before the formation process.

The XRPD patterns of the samples were obtained on a Rigaku equipment Gergenfex RINT2000 using radiation Cu-Ka1 (1.5818 $\AA$ ) at 40 kV, 20 mA, between $20^{\circ} \leq \theta \leq 80^{\circ}$ with a scan speed $0.02^{\circ} / \mathrm{min}$. The data interpretation was based on the Powder Diffraction File (PDF) number 44-0872, 45-1416 e 72-2440 (JENKINS, 1986).

\section{RESULTS AND DISCUSSION}

The results of the visual, chemical, and electrical characterization are presented in this section. It is important to explain that all steps in the battery industrial process are checked, but the formation process. Thus, if some problem occurs with the battery after sale, it is attributed to failure on the formation process. The final test to ensure the quality control of battery is done by sampling $10 \%$ of the lot. Consequently, some batteries that do not achieve the quality standard, were not checked in the final quality control, and were sold to batteries stores (auto parts and other representatives), are received back by the industry and reprocessed.

\subsection{Formation process: manual and automated control}

To verify the influence on the use of automated sources in replacing the manual ones in the battery formation process, a plan for the $54.3 \mathrm{Ah}$ battery model (Ah) was applied. This plan can be seen in Figure 5, wherein the programmed current value is given by the red line. The blue line representing the self-correction of the electric current due to the large variation tendency of the internal electrical resistance of the battery during the formation process. 


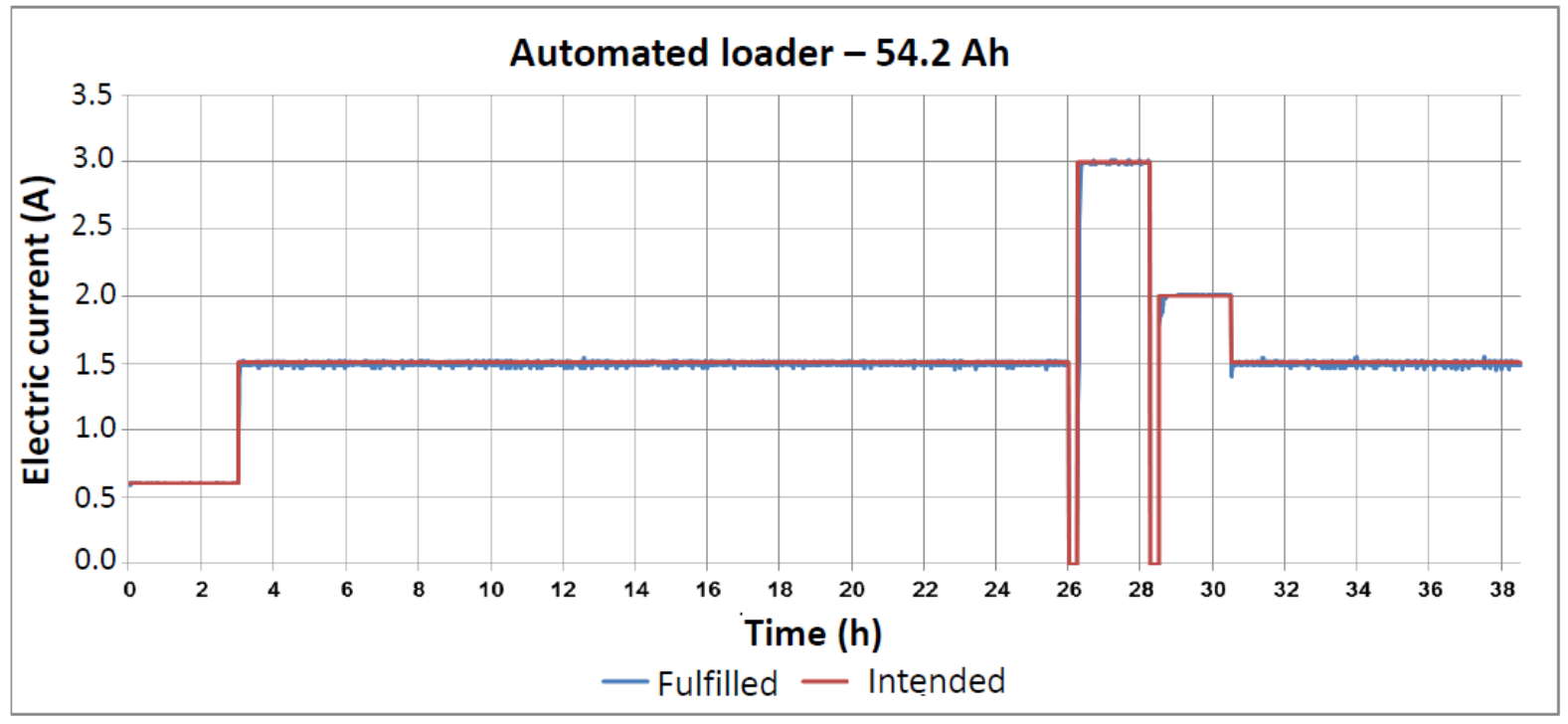

Figure 5: Data of formation of the automated current source.

In terms of current load, the automated source supplied 54.2 Ah to the battery, with only a difference of $0.18 \%$ in relation to the planned deviation, considered negligible. In the process using the manual source, this behavior was not possible to be reproduced, being the control of these parameters infeasible and of low productivity.

\subsection{Visual analysis of the formed positive plate}

Visual analysis of the positive plates was carried out and the results presented. Figure 6 shows the positive battery plates when the formation process was used: (a) manual source and (b) automated source.
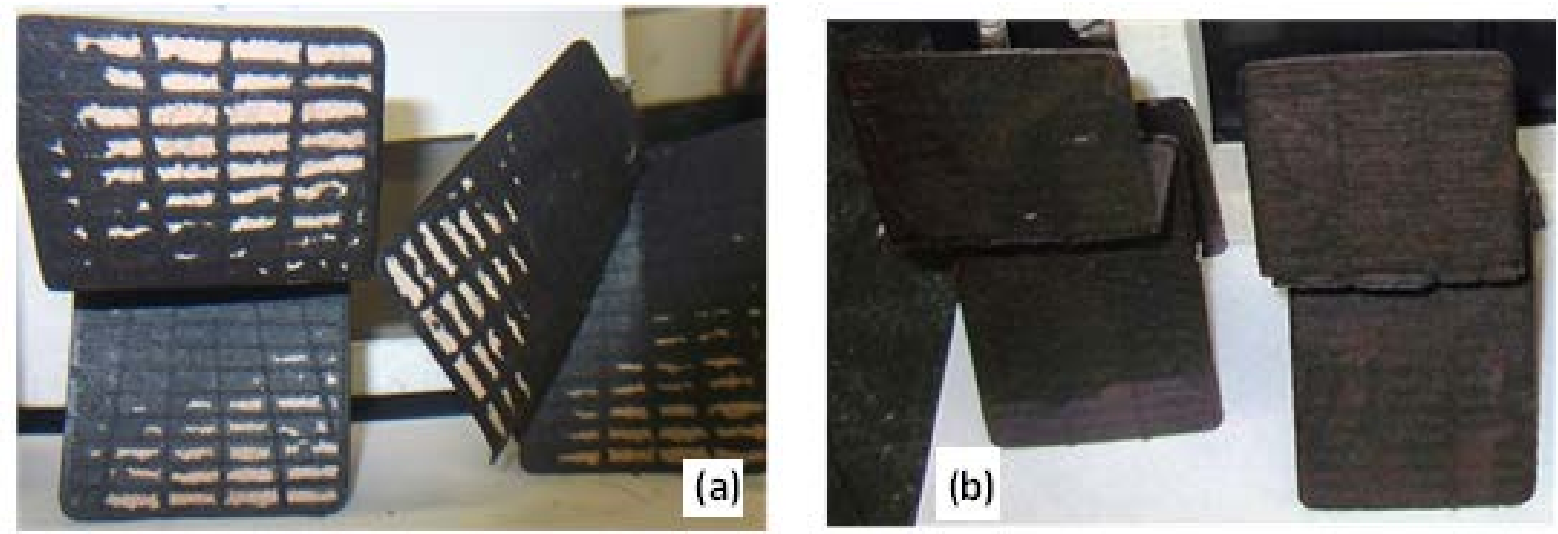

Figure 6: Positive plates of lead-acid battery: (a) formation manual process and (b) automated formation process.

The visual inspection shows clearly the difference on the quality of positive plate formed in the automated process. In Figure 6a, the yellowish color indicates that the precursor materials (basic lead sulfates and lead oxide) were not completely 
converted to $\mathrm{PbO}_{2}$ during the formation process. The higher the amount of active material, better the battery efficiency. Consequently, if the plate presents regions in which the precursor materials were not converted to active material, its effectiveness will be diminished.

The homogeneously distributed brownish black staining on the positive plate, formed in automated process, can be observed in the Figure 6b. It indicates that the $\mathrm{PbSO}_{4}$ has been completely oxidized to lead oxide.

The current density in the formation of lead-acid battery is critical to the growth $\mathrm{PbO}_{2}$ (PAVLOV, 2003). Thus, it is very important that the current source feeds the positive plate with a constant current density. Based on the visual analysis, it is possible to verify that the automated source ensures a formation process of the lead-acid battery with higher quality than the manual one.

\subsection{X-ray diffraction}

The process of lead-acid battery formation occurs by chemical conversion of precursor materials to the active $\alpha-\mathrm{PbO}_{2}$ and $\beta-\mathrm{PbO}_{2}$ phases. The greater efficiency of the battery formation process, the greater the amount of these phases in the positive plate. The $\alpha-\mathrm{PbO}_{2}$ shows a higher life-time and mechanical strength, being preferable to be formed in positive plate of stationary batteries. Meanwhile, the $\beta$ $\mathrm{PbO}_{2}$ phase preferably occurs in acidic medium because it is more stable electrochemically and offers better performance, being interesting for starter batteries (BODE, 1977).

To build up the positive plate, pure lead is grinded in a ball mill. This process results in a powder containing 25 to $30 \%$ wt of free lead and 70 to $75 \%$ wt of lead oxide in its most stable structurally, the $\alpha-\mathrm{PbO}$ tetragonal. To this powder is added lead sulfate and additives, and then, this sludge is applied on the lead grid. The resulting plate is transferred to the oven at $60-80^{\circ} \mathrm{C}$ during $72 \mathrm{~h}$, for curing process; after then, is conducted to the formation process.

Figure 7 shows the XRPD patterns of the positive plate material before and after manual or automated formation process. It was identified the predominance of $\alpha-\mathrm{PbO}$ phase in the sludge sample. This is very interesting because this phase is preferably converted during the formation process in $\beta-\mathrm{PbO}_{2}$ phase. However, the $\beta$ - 
DOI: 10.14807/ijmp.v8i1.498

$\mathrm{PbO}$ phase was also identified, what explain the presence of the $\alpha-\mathrm{PbO}_{2}$ phase in the manual and automated sources samples.

The XRPD pattern of automated process shows only the presence of $\beta-\mathrm{PbO}_{2}$ and $\alpha-\mathrm{PbO}_{2}$ phases, what is quite desirable. In contrast, the XRPD pattern of manual process shows the presence of $\alpha-\mathrm{PbO}$ and $\beta-\mathrm{PbO}$ phases. These results revealed that the main cause of battery failure is associated to the deficiency in the oxidation of the precursor materials into the active material during the formation process. Thus, the automated control of the formation process is more suitable to achieve high quality of the battery performance. The lead oxide phase evolution from a-PbO to $\beta-\mathrm{PbO}_{2}$ phase was also identified in the studies of Palmer (2008) and Pavlov (2011).

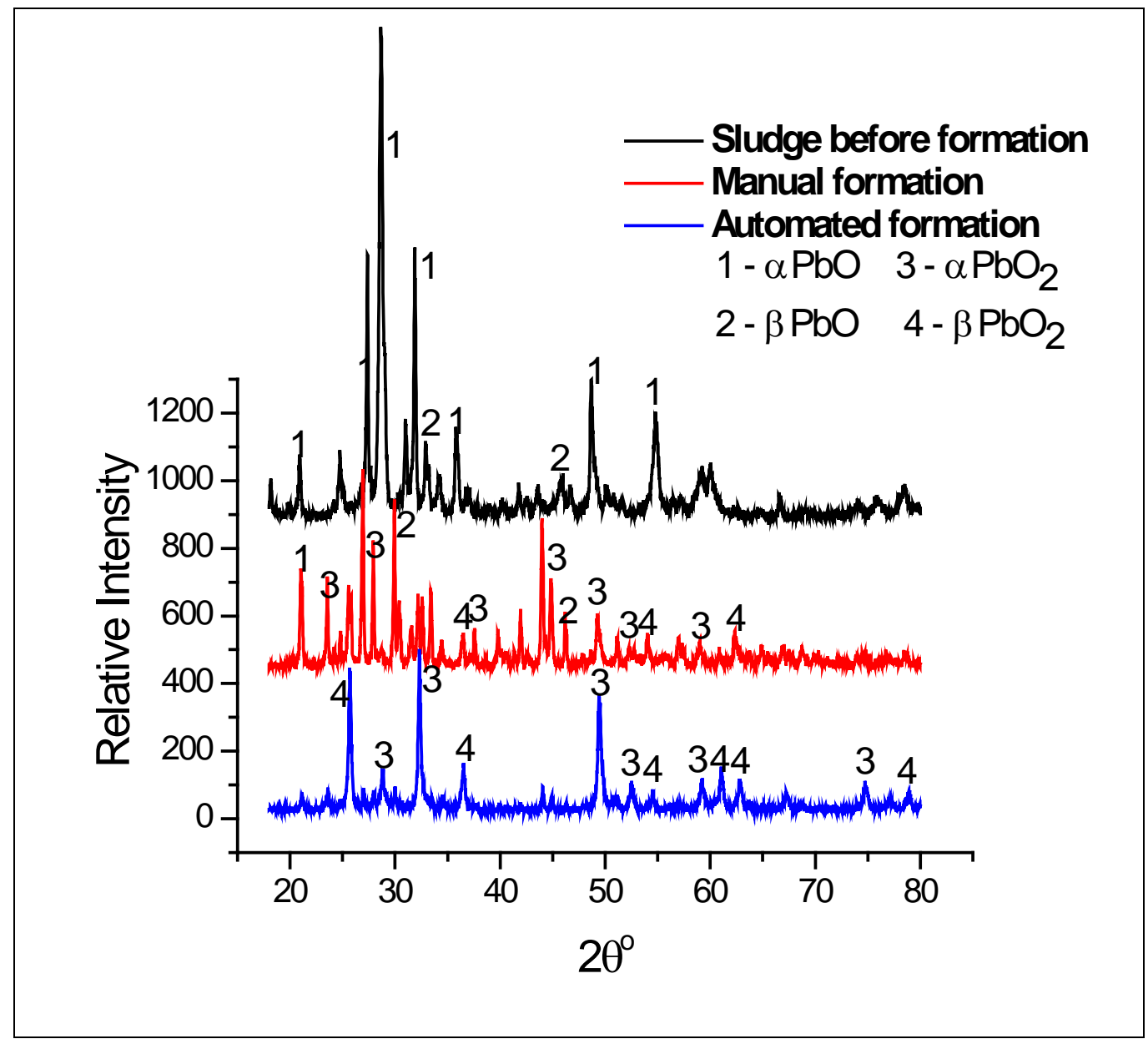

Figure 7: XRPD pattern of the positive plate before and after formation process using manual and automated source. 
DOI: $10.14807 /$ ijmp.v8i1.498

\subsection{Electrical tests}

The batteries produced using both manual and automated formation processes were evaluated by electrical tests. They were conducted using the methodology adopted by Inmetro, and described in the NBR 15941:2012 (ABNT 2012). The test of nominal capacity was performed at $25^{\circ} \pm 2^{\circ} \mathrm{C}$ in 10 -hour discharge rate $\left(\mathrm{C}_{10}\right)$, because of the batteries studied in this work are used in motorcycles. If the battery were produced for use in car, testing is performed in 20-hour system $\left(\mathrm{C}_{20}\right)$.

The battery is considered approved if the value of the capacity measure $\left(\mathrm{C}_{20}\right.$ or $\mathrm{C}_{10}$ ) is greater than or equal to $95 \%$ of the rated capacity specified on the label for new batteries, collected from the manufacturer or trade up to 90 days after its manufacture. Table 3 shows the results for the electrical testing $\mathrm{C}_{10}$.

Table 3: Results of the electrical tests - $\mathrm{C}_{10}$ capacity.

\begin{tabular}{cccc}
\hline Battery & $\begin{array}{c}\text { Capacity } \mathrm{C}_{10} \\
(\mathrm{Ah})\end{array}$ & $\begin{array}{c}\text { Capacity } \mathrm{C}_{10} \text { Minimum } \\
\text { standard }\end{array}$ & Result \\
\hline Automated & 6.13 & $5.0 \mathrm{Ah}$ & OK \\
Manual & 4.72 & $5.0 \mathrm{Ah}$ & NOK \\
\hline
\end{tabular}

OK: passed on the test

NOK: not passed on the test

It was observed that the battery formed using automated source achieved a $\mathrm{C}_{10}$ current capacity $22.6 \%$ higher than the minimum required. Already the battery formed using manual source did not achieve the standard value (NOK) for this test, reaching a current capacity $5.6 \%$ lower.

To support the electrical $\mathrm{C}_{10}$ tests, electrical tests of cold start current - "Cold Crank Ampère" or "Cold Cranking Amps" (CCA) - were performed. This assay was performed at $10^{\circ} \mathrm{C}$, and the time (seconds) required reaching the 6 volts voltage in the case of motorcycles batteries.

In test CCA for the motorcycles batteries are considered approved if the time measured in discharge up to $6 \mathrm{~V}$ is greater than or equal to that specified on the product label (BRAZIL, 2012). Results of the CCA test are presented in the Table 4. 
DOI: 10.14807/ijmp.v8i1.498

Table 4: Results of the electrical testing of cold start current: CCA.

\begin{tabular}{cccc}
\hline $\begin{array}{c}\text { Battery } \\
\text { formation }\end{array}$ & $\begin{array}{c}\text { CCA 40A } \\
(\mathbf{s})\end{array}$ & $\begin{array}{c}\text { CCA 40A } \\
\text { Minimum }\end{array}$ & Result \\
\hline Automated & 151 & $144 \mathrm{~s}$ & OK \\
Manual & 84 & $144 \mathrm{~s}$ & NOK \\
\hline
\end{tabular}

OK: passed on the test

NOK: not passed on the test

It was observed that the battery using automated formation process also surpassed the standard value in $4.9 \%$ of the time for supplying a constant electric current of $40 \mathrm{~A}$. The tests of the batteries using the manual formation process revealed that these ones also did not reach the required by the standard for this test (NOK), reaching only $58.3 \%$ of the standard value.

\subsection{Economic evaluation}

The economic evaluation for the automated formation process line in the industrial production of lead-acid VLRA batteries for motorcycles was carried out. It was taken in account the fact of 580,000 batteries/year were processed in the studied industry in the base year of 2014-2015. Since then, 33,000 batteries $(5.69 \%)$ were reprocessed by deficiency in the formation process. This number is related only to those batteries returned to the industry after failure detection by the users.

The batteries are composed by electrical association of 15 elements connected in series, resulting in 2,200 circuits to be reworked of the total batteries with defect. It is needed to, approximately, 10 hours of operation with electric current of $1.2 \mathrm{~A}$, and a consumption electricity of 3.6 kilowatt-hour (kWh). Thus, it is estimated that over a period equivalent to one year, the electricity consumption is about $7,920 \mathrm{kWh}$. In using the automated formation process of the batteries, this energy consumption could be avoided, since the process is more efficient.

At first, it appears that this economy (by not re-processing of batteries) will not result in significant amounts, ie annual US $\$ 16,584.48$, considering the average cost as US\$ 0.60 per kWh for the industrial electricity (CPFL, 2015). However, it is feasible for the environmental aspects, considering that the energy matrix in Brazil is based on hydroelectric power plants. According to Machado (2015) 3,600 liters of water are needed to produce $1 \mathrm{kWh}$ in a hydroelectric. So, the using of automated source is able to save approximately $28,512 \mathrm{~m}^{3}$ of water annually. 
INDEPENDENT JOURNAL OF MANAGEMENT \& PRODUCTION (IJM\&P)

http://www.ijmp.jor.br

v. 8, n. 1, January - March 2017

ISSN: 2236-269X

DOI: $10.14807 /$ ijmp.v8i1.498

One stand in the industrial line is exclusive to the battery rework. Thus, when the production of NOK battery is avoided, this stand is available for producing about 41,250 new batteries by year.

The cost to replace manual to the automated source is estimated at US\$ $523,000.00$ (500 unities at US\$ 1,046.00), once only the source are object of replacing; all the other dispositive are the same used in manual source control. As the industrial price average sale is US\$ 15.00 per battery, automation will result about US\$ $618,750.00$ on the annual revenue of the industry, only considering the 41,250 new batteries produced by using of the free stand in the production line. Thus, the investment can be paid in one year. After that, the automation of the formation process will represent an additional turnover of about US $\$ 618,750.00$ a year.

\section{CONCLUSION}

This study showed the advantages of automating the formation process of the lead-acid battery production. The visual analysis, as well as, the XRPD analysis demonstrated that the manual process is not able to convert the precursor materials to the active $\alpha-\mathrm{PbO}_{2}$ and $\beta-\mathrm{PbO}_{2}$ phases. This indicated that a constant and stable control of the current density in the formation process is essential to achieve the high efficiency of the batteries. Thus, the replacement of manual source for automated is relevant, since it increases the battery quality; consequently, it saves energy and water resources, improves the use of lead source, decreases pollution footprint associated for battery manufacture (rework), and is cost-effective.

\section{REFERENCES}

ABNT (2012) Associação Brasileira de Normas Técnicas. NBR 15941:2012 -

Baterias chumbo-ácido para motocicletas, triciclos e quadriciclos Especificação e métodos de ensaios. Rio de Janeiro, 2012.

ABNT (2008) Associação Brasileira de Normas Técnicas. NBR ISO 9001:2008 -

Sistema de Gestão da Qualidade: Requisistos. Rio de Janeiro, 2008.

ABNT (2004) Associação Brasileira de Normas Técnicas. NBR ISO 14001:2004 Sistema da Gestão Ambiental: Requisistos com orientações para uso. Rio de Janeiro, 2004.

Bode H. (1977) Lead Acid Batteries, Wiley-Interscience, New York, 1977.

Brazil (2015) INMETRO. Instituto Nacional de Metrologia, Qualidade e Tecnologia.

Portaria n. ${ }^{\circ}$ 199, de 16 de abril de 2015. Requisitos de Avaliação da

Conformidade para Baterias Chumbo-Ácido para Veículos Automotivos. 
Brazil (2012) INMETRO. Instituto Nacional de Metrologia, Qualidade e Tecnologia. Portaria n. ${ }^{\circ}$ 239, de 09 de maio de 2012. Regulamento Técnico da Qualidade para Baterias chumbo-ácido para veículos automotores.

Brazil (2011) INMETRO. Instituto Nacional de Metrologia, Qualidade e Tecnologia. Portaria n. ${ }^{\circ}$ 482, de 19 de dezembro de 2011. Regulamentação de Baterias chumbo-ácido para veículos automotores.

Brazil (2011) INMETRO. Instituto Nacional de Metrologia, Qualidade e Tecnologia. Portaria n. ${ }^{\circ}$ 301, de 21 de julho de 2011. Requisitos de Avaliação da Conformidade para Componentes Automotivos.

CHEN, H. et al. (1996) Study and application of several-step tank formation of lead/acid battery plates. Journal Power Sources, v. 59, n. 1-2, p. 59-62.

$\mathrm{CHO}$, J. et al. (2015) Commercial and research battery techonologies for electrical energy storage applications. Progress in Energy and Combustion Science, n. 48, p. 84-101.

CPFL (2015) Companhia Paulista de Força e Luz. Disponível em: https://www.cpflempresas.com.br/institucional/tarifas.aspx?emp=CPFL.

FERG, E. et al. (2013) The testing of batteries linked to supercapacitors with electrochemical impedance spectroscopy: A comparison between Li-ion and valve regulated lead acid batteries. Journal of Power Sources, n. 226, p. 299-305.

GONZÁLEZ, I. et al. (2012) Estimation of the state-of-charge of gel leadacid batteries and application to the control of a stand-alone wind-solar test-bed with hydrogen support. International Journal of Hydrogen Energy, v. 37, n. 15, p.11090-11103.

GOU, J. et al. (2014) Modeling of the cranking and charging processes of conventional valve regulated lead acid (VRLA) batteries in micro-hybrid applications. Journal of Power Sources, n. 263, p. 186-194.

GROSS, M. (2012) Looking for alternative energy sources. Current Biology, v. 22, n. 4 , p. 103-106.

GRUGEON-DEWAELE, S. et al. (1997) Soaking and formation of tetrabasic lead sulfate. Journal Power Sources, n. 64, p. 71-80.

GUERRA, A. et al. (2015) Future scenarios and trends in energy generation in brazil: supply and demand and mitigation forecasts. Journal of Cleaner

Production, n. 103, p.197-210.

HIREMATH, M. et al., 2015. Comparative life cycle assessment of battery storage systemsfor stationary applications. Environmental science \& technology, v. 49, n. 8, p.4825-4833.

JANNATI, M. et al. (2016) A significant reduction in the costs of battery energy storagesystems by use of smart parking lots in the power fluctuation smoothing process of the wind farms. Renewable Energy, v. 87, n. 1, p.1-14.

JAUNCEY, G. E. M. (1945) The Birth and Early Infancy of X-Rays. American Journal of Physics, n. 13, p. 362-379. 
JENKINS, R. (1986) JCPDS - International Centre for Difraction Data - Sample Preparation Methods in X-Ray Powder Diffractrion. Powder Diffraction, v. 1, n. 2, p. 51-63.

KEAR, G. et al., 2012. Development of the all-vanadium redox flow battery for energy storage: a review of technological, financial and policy aspects. International Journal of Energy Research, v. 36, n. 11, p. 1105-1120.

KIESSLING, R. (1992) Lead acid battery formation techniques. Digatron Firing Circuits, Digatron.

KONOVALOV, V. et al. (2015) Potential of renewable and alternative energy sources. IOP Conf. Series: Earth and Environmental Science, n. 27, p. 012068. doi:10.1088/1755-1315/27/1/012068.

LAM, L.T. et al. (1994) Aspects of lead/acid battery manufacture and performance. Journal of Power Sources, n. 48, p. 257-268.

LAWRENCE, E. L. et al. (2002) Effect of soaking time on the positive active material and performance of the valve regulated lead acid battery. Journal of Power

Sources, n. 110, p. 125-132.

MACHADO, M. (2015) Economizar energia elétrica é mais importante que economizar água. Ama Natureza, 2015. Disponível em:

http://amanatureza.com/conteudo/artigos/economizar-energia-eletrica-e-maisimportante-que-economizar-agua Acesso em: 16 nov. 2015.

MACLEAN, H. L.; LAVE, L. B. (2003) Evaluating automobile fuel/propulsion system technologies. Progress in Energy and Combustion Science, n. 29, p. 1-69.

MANES, G. I. (1956) The Discovery of X-Ray. Isis, n. 47, p. 236-238.

MCKENNA, E. (2013) Economic and environmental impact of lead-acid batteries in grid-connected domestic PV systems. Applied Energy, n. 104, p.239-249.

MCKEON, B. (2014) Advanced Lead-Acid Batteries and the Development of Gridcale Energy Storage Systems. Proceedings of the IEEE, v. 102, n. 6, p. 951-963.

MATTESON, S.; WILLIAMS, E. (2015) Residual learning rates in lead-acid batteries: Effects on emerging technologies. Energy Policy, n. 85, p.71-79.

PALMER, R. V. (2008) Estudo da sulfatação durante a formação de placas positivas empastadas de bateria de chumbo-ácido. $108 \mathrm{f}$. Dissertação (Mestrado em Engenharia e Ciências dos Materiais) - Universidade Federal do Paraná, Curitiba, 2008.

PAVLOV, D. (2011) Lead-acid batteries: science and technology. Amsterdam: Elsevier.

PAVLOV, D. et al. (2003) Strap grid tubular plate-a new positive plate for lead-acid batteries: Processes of residual sulphation of the positive plate. Journal of Power Sources, v. 113, n. 2, p. 255-270.

PAVLOV D. in: MACNICOL, B. D.; RAND, D. A. J. (Eds) (1984) Power Sources for Electric Vehicles. Elsevier, Amsterdam, p. 328.

PAVLOV, D. et al. (1972) Mechanism of the Processes of Formation of Lead-Acid Battery Positive Plates. Journal of the Electrochemical Society, v. 119, n. 1, p. 819. 
PITATOWICZ, G. et al. (2015) A critical overview of definitions and determination techniques of the internal resistance using lithium-ion, lead-acid, nickel metal-hydride batteries and electrochemical double-layer capacitors as examples. Journal of Power Sources, n. 296, p. 365-376.

PROUT L. (1993) Aspects of lead/acid battery technology 4. Plate formation. Journal Power Sources, v. 41, n. 1-2, p. 195-219.

RADUCAN, E.; MORARU, L. (2011) Energy Storage Systems. Journal of Science and Arts, v. 14, n. 1, p. 103-108.

RAND, D. A. J. et al. (2004) Valve-regulated lead-acid batteries. Amsterdam; Boston: Elsevier.

SAUER, D. U.; WENZ, H. (2008) Comparison of different approaches for lifetime prediction of electrochemical systems-Using lead-acid batteries as example. Journal of Power Sources, n. 176, p. 534-546.

SOLOVEICHIK, L. G. (2014) Electrochemistry: Metal-free energy storage. Nature, n. 505, p. $163-165$.

SUBERU, Y. et al. (2014) Energy storage systems for renewable energy power sector integration and mitigation of intermittency. Renewable and Sustainable Energy Reviews, n. 35, p.499-514.

UGURLU, A.; OZTUNA, S. (2015) A comparative analysis study of alternative energy sources for automobiles. International Journal of Hydrogen Energy, v. 40, n. 34, p. 11178-1188.

TAN, Z. et al. (2016) Outage Avoidance and Amelioration Using Battery Energy Storage Systems. IEEE Transactions on Industry Applications, v. 52, n. 1, p. 510.

ZENG, Y. et al. (2015) Investigation of lead dendrite growth in the formation of valveregulated lead-acid batteries for electric bicycle applications. Journal of Power Sources, n. 286, p. 182-192.

ZHOU, Z. et al. (2013) A review of energy storage technologies for marine currentenergy systems. Renewable and Sustainable Energy Reviews, n. 18, p. 390-400.

WATSON, E. C., 1945. The Discovery of X-Rays. American Journal of Physics, $\mathrm{n}$. 13, p. 281-291. 